\title{
The inflammatory response of lymphatic endothelium
}

\section{Journal Article}

\section{Author(s):}

Aebischer, David; Iolyeva, Maria; Halin, Cornelia

Publication date:

2014-04

Permanent link:

https://doi.org/10.3929/ethz-b-000078211

\section{Rights / license:}

In Copyright - Non-Commercial Use Permitted

Originally published in:

Angiogenesis 17(2), https://doi.org/10.1007/s10456-013-9404-3

\section{Funding acknowledgement:}

138330 - Elucidating the impact of inflammation on lymphatic vessel function and on the induction of adaptive immunity (SNF) 


\title{
The inflammatory response of lymphatic endothelium
}

\author{
David Aebischer $\cdot$ Maria Iolyeva $\cdot$ Cornelia Halin
}

Received: 31 May 2013/Accepted: 16 October 2013/Published online: 24 October 2013

(C) Springer Science+Business Media Dordrecht 2013

\begin{abstract}
Lymphatic vessels have traditionally been regarded as a rather inert drainage system, which just passively transports fluids, leukocytes and antigen. However, it is becoming increasingly clear that the lymphatic vasculature is highly dynamic and plays a much more active role in inflammatory and immune processes. Tissue inflammation induces a rapid, stimulus-specific upregulation of chemokines and adhesion molecules in lymphatic endothelial cells and a proliferative expansion of the lymphatic network in the inflamed tissue and in draining lymph nodes. Moreover, increasing evidence suggests that inflammation-induced changes in the lymphatic vasculature have a profound impact on the course of inflammatory and immune responses, by modulating fluid drainage, leukocyte migration or the removal of inflammatory mediators from tissues. In this review we will summarize and discuss current knowledge of the inflammatory response of lymphatic endothelium and of inflammationinduced lymphangiogenesis and the current perspective on the overall functional significance of these processes.
\end{abstract}

Keywords Inflammation - Lymphatic endothelial cells · Lymphangiogenesis - Leukocyte migration · Chemokines · Drainage

\section{Introduction}

Lymphatic vessels (LVs) are present in most vascularized tissues. By absorbing excess tissue fluid and returning it to

D. Aebischer $\cdot$ M. Iolyeva $\cdot$ C. Halin $(\square)$

Institute of Pharmaceutical Sciences, Swiss Federal Institute of

Technology, ETH Zurich, Wolfgang-Pauli Str. 10, HCI H413,

8093 Zurich, Switzerland

e-mail: cornelia.halin@pharma.ethz.ch the blood vascular circulation, LVs essentially contribute to tissue fluid homeostasis [1, 2]. Moreover, LVs transport soluble antigen and leukocytes and therefore are important for immune function [3]. Afferent LVs begin as blindended capillaries, which give rise to collecting vessels that eventually merge and connect with draining lymph nodes (dLNs) (Fig. 1a). Initial lymphatic capillaries are composed of oak-leaf shaped lymphatic endothelial cells (LECs) that are connected by discontinuous, button-like cell junctions [4]. This setup gives rise to characteristic flaps, which represent the prime sites of leukocyte and fluid entry into LVs [4, 5]. By contrast, collecting LVs are ideally adapted for the transport of lymph; here, cuboidal LECs are tightly connected by continuous, zipper-like cell junctions. Moreover, collecting LVs contain valves and are surrounded by a continuous basement membrane and a smooth muscle cell layer [1].

Research of the last 15 years has revealed that the lymphatic network in peripheral tissues and in LNs is highly plastic and undergoes substantial changes under pathologic conditions [1, 2]. For example, tissue inflammation induces rapid, stimulus-specific changes in LEC gene expression and a stimulus-specific expansion and remodeling of the lymphatic network. In humans, inflammation-induced lymphangiogenesis has been reported for psoriasis [6], rheumatoid arthritis [7], inflammatory bowel disease [8], atherosclerosis [9], chronic airway inflammation [10] as well as for transplant rejection [11, 12] and lymphedema [13]. Furthermore, recent animal studies have revealed that inflammation-induced lymphangiogenesis directly impacts the course of inflammatory and immune responses, by modulating fluid drainage, leukocyte migration or the removal of inflammatory mediators from tissues [10, 14-19]. Increasing evidence also suggests that LVs and LECs directly crosstalk with the immune system and 


\section{A Steady state}

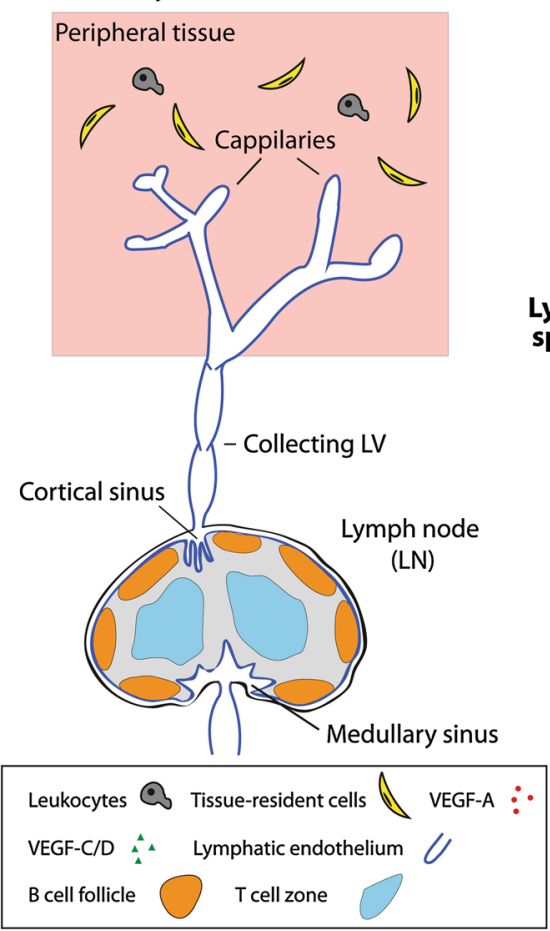

Fig. 1 Inflammation-induced lymphangiogenesis in peripheral tissues and in dLNs. a Anatomy of the lymphatic vasculature at steady state: afferent LVs are composed of initial capillaries and collecting vessels. The lymphatic network in LNs mainly comprises the subcortical and medullary sinus. b During tissue inflammation, lymphangiogenic growth factors, such as VEGF-C/D or VEGF-A, are secreted by tissue-infiltrating leukocytes or by stromal cells. These factors induce a proliferative growth of the lymphatic vasculature by

are involved in antigen presentation and tolerance induction in LNs [20-22]. The latter processes have been the focus of excellent recent reviews [23, 24] and therefore will not be discussed in further detail.

In this review we will introduce the best characterized mediators of inflammatory lymphangiogenesis and summarize current knowledge about inflammation-induced gene expression changes in LECs. Furthermore, we will focus on the morphologic and structural changes of LVs in inflamed tissues and in dLNs. Finally, we will summarize how inflammation-induced lymphangiogenesis and lymphatic remodeling are thought to impact the inflammatory process, by modulating leukocyte trafficking, fluid drainage and chemokine levels in inflamed tissues.

\section{Mediators of inflammation-induced lymphangiogenesis}

The best-studied mediators of inflammation-induced lymphangiogenesis are vascular endothelial growth factor (VEGF)-C and VEGF-A, which are produced by stromal cells like keratinocytes or fibroblasts as well as by
Inflammation

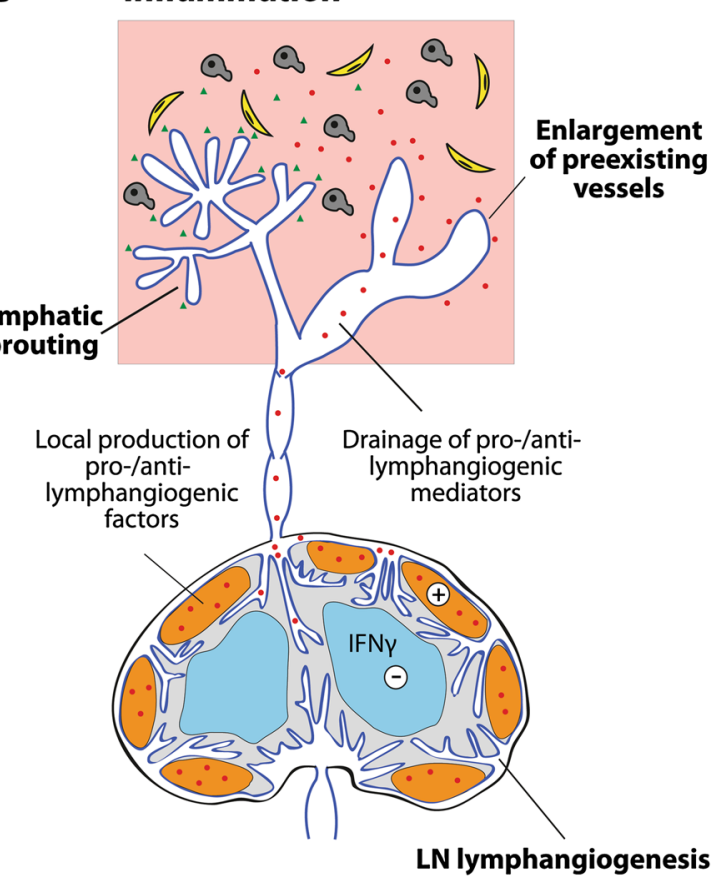

lymphatic sprouting or enlargement of preexisting vessels. At the same time, lymphangiogenesis occurs in dLNs. LN lymphangiogenesis-inducing factors are either produced locally (e.g. VEGF-A produced by $\mathrm{B}$ cells) or drained to the $\mathrm{LN}$ from the inflamed tissue. Depending on the type of inflammatory response induced, LN lymphangiogenesis may be counterbalanced by inhibitory factors (i.e. IFN $\gamma$ produced by activated $\mathrm{T}$ cells)

leukocytes in inflamed tissues [1, 2, 25]. Particularly macrophages are a major source of VEGF-A and VEGF-C [26-28]. In various inflammatory models, depletion of macrophages was shown to significantly reduce lymphangiogenesis [26-29]. Notably, macrophages may also physically contribute to lymphangiogenesis by up-regulating lymphatic marker genes and incorporating into LVs $[11,29]$. Besides VEGF family members, also other leukocyte-derived cytokines contribute to inflammationinduced lymphangiogenesis (Table 1). For example, lymphotoxin (LT) $\alpha$ and $L T \alpha \beta_{2}$ have been implicated in inflammatory lymphangiogenesis during infection or tertiary lymphoid organ formation [30, 31]. Similarly, interleukin 17 (IL-17) was shown to induce lymphangiogenesis in a mouse model of ocular autoimmunity [32], whereas IL-8 promoted LV regeneration and reduced post-surgical lymphedema formation [33]. Interestingly, also some inflammatory cytokines with anti-lymphangiogenic activity have been identified (Table 1). For example, IFN $\gamma$, a mainly $\mathrm{T}$ cell-derived cytokine, reportedly inhibits LECs in vitro and in vivo [34-36]. Moreover, inhibition of transforming growth factor beta (TGF $\beta$ ) was shown to 
Table 1 Inflammatory mediators with documented pro- or antilymphangiogenic activity

\begin{tabular}{|c|c|c|c|}
\hline Mediator & $\begin{array}{l}\text { Lymphangiogenic } \\
\text { activity }\end{array}$ & $\begin{array}{l}\text { In vitro (1) } \\
\text { In vivo (2) }\end{array}$ & References \\
\hline VEGF-C & + & $1 \& 2$ & {$[72,105]$} \\
\hline VEGF-A & + & $1 \& 2$ & {$[72,105]$} \\
\hline $\mathrm{LT} \alpha$ & + & 2 & [31] \\
\hline $\mathrm{LT} \alpha \beta_{2}$ & + & $1 \& 2$ & {$[30,106]$} \\
\hline IL-17 & + & $1 \& 2$ & [32] \\
\hline $\begin{array}{l}\text { IL-8 } \\
\text { (CXCL8) }\end{array}$ & + & $1 \& 2$ & {$[33,107]$} \\
\hline $\mathrm{HGF}$ & + & $1 \& 2$ & [108] \\
\hline IL-3 & + & 1 & [66] \\
\hline $\begin{array}{l}\text { FGF-2 } \\
\text { (bFGF) }\end{array}$ & + & $1 \& 2$ & [65] \\
\hline LPS & + & $1 \& 2$ & {$[61,66]$} \\
\hline CXCL12 & + & $1 \& 2$ & [59] \\
\hline S1P & + & $1 \& 2$ & [109] \\
\hline $\mathrm{TNF} \alpha$ & - & 1 & [35] \\
\hline IL-27 & - & 1 & {$[60]$} \\
\hline $\mathrm{IFN} \alpha$ & - & 1 & [34] \\
\hline $\mathrm{IFN} \gamma$ & - & $1 \& 2$ & [34-36] \\
\hline TGF $\beta$ & - & $1 \& 2$ & {$[37,38]$} \\
\hline CXCL10/11 & - & 1 & {$[60]$} \\
\hline
\end{tabular}

Various inflammatory mediators have been shown to induce or inhibit lymphangiogenesis in vitro or in vivo. Lymphangiogenic activity: (+) pro-lymphangiogenic activity, (-) anti-lymphangiogenic activity. In vitro/in vivo activity: (1) shown to modulate LEC in vitro proliferation, migration, or tube formation, (2) shown to modulate lymphangiogenesis in vivo. HGF hepatocyte growth factor, S1P sphingosine-1-phosphate

enhance lymphangiogenesis in thioglycollate-induced peritonitis [37] and to induce lymphangiogenesis and lymphatic drainage in a murine lymphedema model [38]. Overall, the balance of pro- and anti-lymphangiogenic cytokine expression appears to determine the extent and nature of inflammation-induced lymphangiogenesis. This generates a very flexible system, in which tailored lymphangiogenic responses are initiated, depending on the type of inflammatory immune response elicited.

\section{Inflammation-induced changes in LEC gene expression}

In vitro many inflammatory mediators, such as growth factors, cytokines or pathogen-derived molecules induce LEC proliferation, migration or tube formation and therefore exert a pro-lymphangiogenic activity (Table 1). Conversely, other mediators appear to rather suppress these processes or to mainly modulate the gene expression phenotype of LECs. For example, inflammatory cytokines such as TNF $\alpha$, IFN $\gamma$, IL-1 induce no or little LEC proliferation
[35], but are strong inducers of inflammatory chemokines and adhesion molecules like ICAM-1 and VCAM-1, which participate in leukocyte trafficking [35, 39-41]. In fact, leukocyte trafficking via afferent LVs is typically enhanced in the context of inflammation [3, 42, 43].

\section{Adhesion molecules}

Inflammatory signals have been shown to modulate the expression of ICAM-1 and VCAM-1 [39, 40], P-selectin [40], E-selectin [39, 44], L1CAM [45], ALCAM [46] or CAR [47] in LECs. While some of these molecules contribute to lymphangiogenesis [46, 47], others mediate leukocyte trafficking via afferent LVs [39, 45, 48]. Particularly inflammation-induced ICAM-1 or VCAM-1 were shown to be important for dendritic cell (DC) transmigration into [39, 48] and migration within LVs [49]. LVs in resting tissues express very low levels of ICAM-1 and VCAM-1, but these adhesion molecules are strongly upregulated in LECs during tissue inflammation. This might explain why DC migration in absence of inflammation occurs independently of ICAM-1 or VCAM-1 binding integrins [50]. By contrast, blockade of ICAM-1, VCAM-1 or of the DC-expressed integrin LFA-1 significantly reduced DC migration to dLNs in the context of skin inflammation [39, 48]. Interestingly, interactions between LEC-expressed ICAM-1 and DCexpressed Mac-1 (CD11b) occurring in the process of DC migration to dLNs were also shown to modulate the maturation state and function of DCs [51].

\section{Chemokines}

Various chemokines are upregulated in LECs in response to inflammatory signals (Table 2). The chemokine with the best documented role in leukocyte trafficking into LVs is CCL21, which attracts CC-chemokine receptor 7 (CCR7) expressing leukocytes, such as DCs or T cells [3]. Tissue inflammation was shown to upregulate CCL21 protein expression in vivo [40]. Moreover, TNF $\alpha$, VEGF-C as well as transmural flow were identified as inducers of CCL21 expression in LECs [42, 52, 53] (Table 2). Interestingly, a substantial fraction of CCL21 is stored intra-cellularly in vesicles of the Trans-Golgi Network [40, 54]. In vitro treatment of LECs with TNF $\alpha$ was shown to induce rapid secretion of CCL21 from its intracellular stores [55], but it is still unclear how tissue inflammation affects CCL21 secretion in vivo. Interestingly, also neutrophil migration via afferent LVs, which occurs during acute inflammation, is mainly CCR7-dependent [56]. Similarly, CCR7 expression was shown to be the main determinant of regulatory and effector $\mathrm{T}$ cell migration into LVs during acute inflammation [3, 43]. However, the CCR7-dependence of T cell migration into lymphatics appears to be less strong in 
Table 2 Inflammatory mediators inducing chemokine expression in LECs
Various inflammatory stimuli have been shown to induce chemokine expression in LECs in vitro or in vivo. Chemokines written in bold font: protein expression reported.

Chemokines written in regular font: mRNA expression reported

$M D P$ muramyl dipeptide, $L T A$ lipoteichoic acid, $D N F B$ dinitrofluorobenzene

\begin{tabular}{|c|c|c|c|}
\hline $\begin{array}{l}\text { Inflammatory } \\
\text { stimulus }\end{array}$ & $\begin{array}{l}\text { Chemokines } \\
\text { induced }\end{array}$ & Comment & Ref. \\
\hline \multicolumn{4}{|l|}{ in vitro } \\
\hline $\begin{array}{l}\text { TLR ligands } \\
\text { (TLR2/3/4/6/8/9) }\end{array}$ & $\begin{array}{c}\text { CCL5, 20, 21; } \\
\text { CXCL8/9/10/11/12 }\end{array}$ & $\begin{array}{l}\text { stimulus-specific } \\
\text { responses }\end{array}$ & {$[41]$} \\
\hline $\begin{array}{l}\text { TLR ligands } \\
\text { (TLR1/2/3/4/6/9) }\end{array}$ & $\begin{array}{l}\text { CCL2/5 } \\
\text { CXCL8 }\end{array}$ & $\begin{array}{l}\text { stimulus-specific } \\
\text { responses }\end{array}$ & {$[62]$} \\
\hline LPS & $\begin{array}{c}\text { CCL2/3/5/7/8/20 } \\
\text { CXCL1/3/5/6/8 }\end{array}$ & & {$[44]$} \\
\hline LPS & $\begin{array}{l}\text { CCL2/5 } \\
\text { CX3CL1 }\end{array}$ & & [61] \\
\hline TNF $\alpha$ & $\begin{array}{c}\text { CCL2/5/20/21 } \\
\text { CXCL2/5 } \\
\text { CX3CL1 }\end{array}$ & & {$[39]$} \\
\hline TNF $\alpha$ & CCL21 & & {$[55]$} \\
\hline $\mathrm{TNF} \alpha / \mathrm{IFN} \gamma$ & $\begin{array}{c}\text { CCL2/7 } \\
\text { CXCL5/9/10 }\end{array}$ & & {$[40]$} \\
\hline MDP / LTA & $\begin{array}{l}\text { CCL2/7 } \\
\text { CXCL5 }\end{array}$ & & {$[40]$} \\
\hline Transmural flow & CCL21 & & {$[53]$} \\
\hline VEGF-C & CCL21 & & {$[52]$} \\
\hline \multicolumn{4}{|l|}{ in vivo } \\
\hline LPS injection & CCL2 & \begin{tabular}{|l|} 
peritoneal \\
inflammation
\end{tabular} & {$[61]$} \\
\hline $\begin{array}{l}\text { CHS response to } \\
\text { DNFB }\end{array}$ & CXCL12 & skin inflammation & {$[57]$} \\
\hline $\begin{array}{l}\text { CHS response to } \\
\text { oxazolone }\end{array}$ & $\begin{array}{c}\text { CCL2/7/8/21 } \\
\text { CXCL1/5/9/10 }\end{array}$ & skin inflammation & {$[40]$} \\
\hline CFA injection & $\begin{array}{l}\text { CCL2/7/21 } \\
\text { CXCL5 }\end{array}$ & skin inflammation & {$[40]$} \\
\hline VEGF-C & CCL21 & \begin{tabular}{|l|}
$\begin{array}{l}\text { Intradermal } \\
\text { injection }\end{array}$ \\
\end{tabular} & [52] \\
\hline TNF $\alpha$ & CCL21 & $\begin{array}{l}\text { Intradermal } \\
\text { injection }\end{array}$ & [42] \\
\hline Lymph flow & CCL21 & \begin{tabular}{|l}
$\begin{array}{l}\text { Iymphedema or } \\
\text { overhydration }\end{array}$ \\
\end{tabular} & [53] \\
\hline $\begin{array}{l}\text { Pancreatic islet } \\
\text { inflammation }\end{array}$ & $\begin{array}{l}\text { CCL2, CCL21 } \\
\text { CXCL10 }\end{array}$ & $\begin{array}{l}\text { mouse model of } \\
\text { autoimmune } \\
\text { diabetes }\end{array}$ & {$[110]$} \\
\hline
\end{tabular}

the context of chronic inflammation [43], suggesting a role for other inflammation-induced chemokines or other chemotactic molecules under this condition.

Besides CCL21, various other chemokines are upregulated in LECs in response to inflammatory signals (Table 2), but thus far only two further chemokines have been shown to support leukocyte migration into afferent LVs. Inflammation-induced CXCL12 reportedly enhanced the migration of CXCR4-expressing dermal DCs and Langerhans cells to dLNs [57]. Moreover, LEC-expressed CX3CL1 (fractalkine) was recently shown to support DC transmigration across lymphatic endothelium and the overall trafficking process from inflamed tissue to dLNs [58]. On the other hand, experiments performed in $\mathrm{CCR}^{-1-}$ mice revealed that DC migration to dLNs remained strictly CCR7-dependent in the context of skin inflammation [40]. Thus, although CCL21/CCR7 signaling remains of key importance for DC migration during inflammation, also other LEC-expressed chemokines contribute to this process, possibly by affecting distinct steps in the migration cascade.

In analogy to the role of chemokines in angiogenesis, increasing evidence suggests that inflammation-induced chemokines may be involved in the regulation of lymphangiogenesis. For example CXCL12 reportedly induces lymphangiogenesis in vitro and in vivo [59]. Similarly, CXCL8 (IL-8), which is upregulated in LECs in response to various inflammatory stimuli, reportedly enhances lymphangiogenesis [33, 41]. By contrast, inflammationinduced CXCL10 and CXCL11 (Table 2) were shown to exert anti-lymphangiogenic activity in vitro [60]. It has also been suggested that the upregulation of chemokines might serve to indirectly support lymphangiogenesis. In a murine peritonitis model, inflammation-induced chemokine expression in LECs was responsible for the attraction and association of macrophages with LVs, what in turn induced lymphangiogenesis by macrophage-derived lymphangiogenic growth factors [61].

\section{Stimulus-specific changes in LEC gene expression}

Several studies have revealed that many changes in LEC gene expression occur in a highly stimulus-specific manner [35, 39-41, 62]. For example, performing gene expression analyses of LECs isolated from inflamed or resting murine 
ear skin we have recently observed that inflammation elicited by a contact hypersensitivity (CHS) response to oxazolone or by CFA injection induced a similar degree of tissue swelling, but a differential upregulation of inflammatory chemokines (Table 2) and of adhesion molecules (e.g. ICAM-1, P-selectin) [40]. Stimulus-specific upregulation of chemokines and of ICAM-1 or VCAM-1 was also observed in other studies when treating LECs in vitro with different cytokines or with Toll-like receptor (TLR) ligands $[35,39-41,62]$. It is likely that stimulus-specific upregulation of trafficking molecules serves to fine-tune leukocyte migration or other chemokine-induced responses in LECs in the context of the ongoing immune response.

Inflammation also modulates the expression of lymphatic marker genes in a stimulus-specific manner. Various stimuli reportedly induce down-regulation of the hyaluronan receptor LYVE-1 in LECs [10, 40, 63]. The significance of this down-regulation is presently unclear, but recent findings suggest that loss of LYVE-1 may alter LEC barrier function [64]. Interestingly, LYVE-1 was also shown to bind and to enhance the activity of fibroblast growth factor-2 (FGF2), an inflammation-induced factor with reported lymphangiogenic activity [65]. Also the transcription factor Prox-1 and its target gene VEGFR-3 were shown to be down-regulated in LECs in the context of CHS-induced skin inflammation [15, 40]. By contrast, Prox-1 and VEGFR-3 expression remained constant during tissue inflammation induced by CFA injection [40], whereas both genes were upregulated in LVs in a mouse model of thioglycollate-induced peritonitis [66]. It is perceivable that modulation of Prox-1 affects lymphatic differentiation, whereas changes in VEGFR3 expression likely affect LEC responsiveness towards inflammationinduced VEGF-C.

\section{Inflammation-induced changes in afferent LVs}

Inflammation leads to a rapid dilation of LVs in tissues [1, 67, 68]. Additionally, the size of the lymphatic network increases due to proliferative expansion [68-70]. This may feature a proliferative enlargement of preexisting vessels [67] or the sprouting of new LVs [27, 28, 66] (Fig. 1b). Interestingly, the extent of lymphangiogenic sprouting versus expansion of preexisting vessels appears to depend on the lymphangiogenesis-inducing stimuli. VEGF-A was shown to mainly induce LV enlargement [71, 72], whereas VEGF-C induced sprouting lymphangiogenesis [72, 73]. Besides changing lymphatic morphology, persistent inflammation may also alter the typical organization of lymphatic cell junctions [4]. In a model of chronic airway inflammation induced by infection with Mycoplasma pulmonis, the characteristic button-like cell junctions were replaced by continuous, zipper-like junctions [74]. The functional significance of this conversion is not known, but it is likely that these structural differences affect lymphatic drainage or leukocyte migration.

\section{Inflammation-induced changes in the lymphatic network in dLNs}

Inflammation-induced lymphangiogenesis does not only affect the inflamed tissue but also extends to dLNs [36, 6870, 75] (Fig. 1b). In a mouse model of skin inflammation induced by immunization with complete Freund's adjuvants (CFA), LN lymphangiogenesis was mainly driven by VEGF-A secreted from LN-resident B cells. By contrast, in a mouse model of chronic skin inflammation induced by a CHS response to oxazolone, LN lymphangiogenesis was shown to be mediated by VEGF-A that was drained to the LN from its production site in the inflamed skin [68]. Different from nodal B cells, activated $\mathrm{T}$ cells appear to have a negative impact on LN lymphangiogenesis. IFN $\gamma$ secreted by activated $\mathrm{T}$ cells reportedly inhibits LN lymphangiogenesis and limits the size of the lymphatic network in the LN T cell area in steady state and in inflammation [36, 75]. Thus, it appears that depending on the inflammatory stimulus and the type of immune response induced, the pattern and extent of LN lymphangiogenesis may vary. As a further illustration of this hypothesis; lipopolysaccharide (LPS) injection into the skin was shown to promote LN lymphangiogenesis, whereas injection of the $\mathrm{T}$ cell mitogen concanavalin-A did not increase the lymphatic vasculature in the dLN, although both agents accounted for potent inflammatory reactions at the site of injection [36].

Intriguingly, experiments in mouse models of lymphedema have revealed that lymphedema formation was reduced and lymphatic regeneration and drainage were enhanced in mice devoid of $\mathrm{T}$ cells [75] or upon depletion of $\mathrm{CD}^{+} \mathrm{T}$ cells [76]. The latter findings suggest that T-cell-derived mediators might also negatively impact lymphangiogenesis and LV function outside of the LN. Regarding to functional significance of inflammationinduced LN lymphangiogenesis, experimental evidence suggests that this process serves to regulate leukocyte migration to and from LNs. In the context of CFA-induced inflammation, VEGFR-2- and VEGFR3-mediated blockade of LN lymphangiogenesis was shown to reduce DC migration to dLNs [69] as well as lymphocyte egress via efferent lymphatics [70]. On the other hand, LECs in LNs have been shown to present antigen to $\mathrm{T}$ cells and to participate in tolerance induction [21, 22]. Thus, it is likely that LN lymphangiogenesis directly modulates the induction of adaptive immunity in LNs [23, 24]. 


\section{Role of afferent LVs in modulating inflammatory and immune responses}

Several studies have shown that tissue inflammation not only alters LV morphology but also changes lymphatic function, for example the capacity of LVs to mediate leukocyte migration or to drain tissue fluids [10, 14-19]. Such changes in LV function profoundly impact the persistence or resolution of tissue inflammation. In the following sections, the impact of alterations in LV immune and drainage functions on the inflammatory response shall be discussed in greater detail.

\section{Leukocyte trafficking}

Besides removing tissue fluids and inflammatory mediators, the lymphatic network is also thought to contribute to the downregulation and resolution of inflammation by facilitating tissue exit of leukocytes. For example, regulatory $\mathrm{T}$ cells have been identified as a major cell type emigrating from inflamed skin to dLNs, where they are thought to downregulate cutaneous immune responses [77]. Moreover, the clearance of tissue-infiltrating macrophages via LVs has been discussed as an important step in the resolution of inflammation [78, 79], but also contradicting data exist on this topic [80].

On the other hand, tissue exit of leukocytes via LVs may also enhance the inflammatory process. For example, an activated and expanded lymphatic network is known to increase the migration of antigen-presenting DCs to dLNs, what may support the induction of adaptive immunity [16, 69]. This is particularly relevant during organ transplantation, where studies in humans have revealed a positive correlation between lymphangiogenesis and transplant rejection $[11,12]$. Moreover, in animal models, blocking lymphangiogenesis was shown to significantly reduce DC migration and graft rejection [16-19]. However, organ transplantation represents a special condition, in which lymphatic connectivity with dLNs need to be formed de novo, and additionally strong alloimmune responses may be induced. By contrast, in the context of endogenous tissues with preexisting lymphatic vasculature and immune connectivity with dLNs, blockade of inflammation-induced lymphangiogenesis was shown to exacerbate the inflammatory response, likely due to the enhancement of tissue edema $[10,14,15]$.

\section{LV drainage}

Increasing evidence suggests that lymphatic drainage is frequently compromised in the context of chronic inflammation, such as in psoriasis [81, 82] or Morbus Crohn [83, 84]. However, in animal models, both inflammationinduced enhancement and reduction of lymphatic drainage has been observed. For example, injection of LPS [27], reportedly enhanced lymphatic drainage in the skin, whereas in the diaphragm drainage was reduced in a model of LPS-induced peritonitis [28], suggesting that the response of the lymphatic vasculature to an inflammatory stimulus might not be uniform but organ-specific. However, such organ-specific differences, have not been studied in great detail thus far. By contrast, an abundant literature indicates that the nature of the inflammatory stimulus has a great impact on lymphatic drainage function. For example, in the skin, LV drainage reportedly was reduced in the context of CHS- [85, 86] and UVB-induced [15, 87] skin inflammation, whereas skin inflammation induced by transgenic overexpression of interleukin-4 [88] lead to enhanced lymphatic drainage. Several studies have also shown that VEGF-A-induced lymphangiogenesis generated less functional LVs as compared to lymphangiogenesis induced by VEGF-C and VEGF-D [15, 71, 87, 89]. In general, activation of the VEGFR-3 pathway appears to be an effective way of stimulating productive lymphangiogenesis and stimulating lymphatic drainage: genetic overexpression or injection of recombinant VEGF-C was shown to alleviate UV-B or CHS-induced acute and chronic skin inflammation [15, 89, 90] as well as chronic inflammatory arthritis [91], likely by enhancing lymphatic drainage function. By contrast, inhibition of VEGFR-3 signaling impaired lymphatic growth and exacerbated inflammation in mouse models of airway inflammation [10], inflammatory arthritis [14] or chronic skin inflammation [15], likely by promoting tissue edema formation.

Many inflammatory mediators are known to enhance permeability of $\mathrm{BVs}$, but only few in vivo reports about effects on LV permeability exist. Nitric oxide (NO) and VEGF-A were shown to contribute to the leakiness of dermal LVs in the context of UV-B-induced inflammation [87, 92]. In vitro, inflammatory mediators such as $\mathrm{TNF} \alpha$, IL-1, histamine, thrombin and VEGF-C were shown to decrease the barrier function of LEC monolayers [35, 93, 94]. Moreover, inflammation was also shown to impact the pumping function of lymphatic collectors. Specifically, various inflammatory mediators, such as histamine, prostaglandins or NO were shown to reduce lymphatic pumping [95-97], whereas VEGF-C enhanced pumping [98].

\section{Chemokine scavenging}

In addition to passively draining tissue fluids and inflammatory mediators, LVs have been shown to actively remove chemokines from inflamed tissues. In particular, the chemokine scavenging receptor (CSR) D6, which is expressed by LECs and is upregulated during inflammation [99], was shown to be important for the resolution of tissue inflammation [100, 101]. D6 internalizes and degrades 
inflammatory chemokines (i.e. CCL2, 3, 5, 8, 12, 17, 22), thereby accelerating their elimination from tissues. Moreover, it was recently proposed that D6 functions to ensure selective presentation of CCL21 on LECs, by suppressing inflammatory chemokine binding and accumulation. In inflamed tissues of D6-deficient mice, a massive association of myelomonocytic cells around LVs was observed, leading to obstructed lymphatic drainage and reduced DC migration to dLNs [100]. Thus far, only the function of D6 in LECs has been analyzed. However, it was recently reported that another CSR, namely the CXCL11- and CXCL12-binding CXC chemokine receptor 7 (CXCR7), was upregulated in inflamed LVs [102]. Thus, it is likely that besides D6, further CSRs contribute to the inflammation- and immune-modulating functions of LVs.

\section{Conclusion}

Over the last 15 years a lot of progress has been made in understanding how tissue inflammation alters gene expression in LECs as well as LV morphology and function. The emerging view is that the inflammatory response of the lymphatic endothelium and its impact on LV functionality is very much stimulus-specific and contextdependent. Depending on the inflammatory stimulus and the resulting immune response, different pro-/anti-lymphangiogenic mediators are produced in the tissue. This generates a unique milieu, which impacts the inflammatory response of LECs and the overall nature and extent of lymphangiogenesis. Such stimulus-specific changes in the lymphatic vasculature may greatly influence LV functionality, such as fluid drainage and leukocyte trafficking. Recent data also indicate that the same inflammatory stimulus may have different effects on LV function in different organs $[27,28]$. The latter might be explained by the fact that clear morphologic [103] and gene expression [104] differences exist between LVs in different body parts. However, many of these differences are only now starting to be unraveled. By contrast, already to date abundant evidence suggests that the impact of lymphangiogenesis on tissue inflammation is very much contextdependent. Lymphangiogenesis occurring within transplanted organs (e.g. cornea [16, 17], heart [18], pancreatic islands [19] or kidney $[11,12])$ has been shown to exacerbate tissue inflammation, supposedly by re-establishing connectivity with the immune system in the dLNs and hence contributing to the rejection process. On the other hand, various recent studies reveal that in tissues with a pre-established LV network (e.g. the skin [89], lung [10] or joints $[14,91])$ productive, in particular VEGF-C-mediated, lymphangiogenesis contributes to the resolution of inflammation, supposedly by promoting tissue drainage.
Thus, stimulation or inhibition of lymphangiogenesis could represent an attractive novel therapeutic strategy for reducing chronic inflammation or transplant rejection, respectively.

Acknowledgments $\mathrm{CH}$ gratefully acknowledges financial support from the Swiss National Science Foundation (Grant 310030_138330).

Conflict of interest The authors declare no competing financial interests.

\section{References}

1. Schulte-Merker S, Sabine A, Petrova TV (2011) Lymphatic vascular morphogenesis in development, physiology, and disease. J Cell Biol 193(4):607-618. doi:10.1083/jcb.201012094

2. Alitalo K (2011) The lymphatic vasculature in disease. Nat Med 17(11):1371-1380. doi:10.1038/nm.2545

3. Forster R, Braun A, Worbs T (2012) Lymph node homing of $T$ cells and dendritic cells via afferent lymphatics. Trends Immunol 33(6):271-280. doi:10.1016/j.it.2012.02.007

4. Baluk P, Fuxe J, Hashizume H, Romano T, Lashnits E, Butz S, Vestweber D, Corada M, Molendini C, Dejana E, McDonald DM (2007) Functionally specialized junctions between endothelial cells of lymphatic vessels. J Exp Med 204(10):2349-2362. doi:10.1084/jem.20062596

5. Pflicke H, Sixt M (2009) Preformed portals facilitate dendritic cell entry into afferent lymphatic vessels. J Exp Med 206(13):2925-2935. doi:10.1084/jem.20091739

6. Detmar M, Brown LF, Claffey KP, Yeo KT, Kocher O, Jackman RW, Berse B, Dvorak HF (1994) Overexpression of vascular permeability factor/vascular endothelial growth factor and its receptors in psoriasis. J Exp Med 180(3):1141-1146

7. Wauke K, Nagashima M, Ishiwata T, Asano G, Yoshino S (2002) Expression and localization of vascular endothelial growth factor-C in rheumatoid arthritis synovial tissue. J Rheumatol 29(1):34-38

8. Pedica F, Ligorio C, Tonelli P, Bartolini S, Baccarini P (2008) Lymphangiogenesis in Crohn's disease: an immunohistochemical study using monoclonal antibody D2-40. Virchows Arch 452(1):57-63. doi:10.1007/s00428-007-0540-2

9. Nakano T, Nakashima Y, Yonemitsu Y, Sumiyoshi S, Chen YX, Akishima Y, Ishii T, Iida M, Sueishi K (2005) Angiogenesis and lymphangiogenesis and expression of lymphangiogenic factors in the atherosclerotic intima of human coronary arteries. Hum Pathol 36(4):330-340. doi:10.1016/j.humpath.2005.01.001

10. Baluk P, Tammela T, Ator E, Lyubynska N, Achen MG, Hicklin DJ, Jeltsch M, Petrova TV, Pytowski B, Stacker SA, Yla-Herttuala S, Jackson DG, Alitalo K, McDonald DM (2005) Pathogenesis of persistent lymphatic vessel hyperplasia in chronic airway inflammation. J Clin Invest 115(2):247-257. doi:10. 1172/JCI22037

11. Kerjaschki D, Huttary N, Raab I, Regele H, Bojarski-Nagy K, Bartel G, Krober SM, Greinix H, Rosenmaier A, Karlhofer F, Wick N, Mazal PR (2006) Lymphatic endothelial progenitor cells contribute to de novo lymphangiogenesis in human renal transplants. Nat Med 12(2):230-234. doi:10.1038/nm1340

12. Dashkevich A, Heilmann C, Kayser G, Germann M, Beyersdorf F, Passlick B, Geissler HJ (2010) Lymph angiogenesis after lung transplantation and relation to acute organ rejection in humans. Ann Thorac Surg 90(2):406-411. doi:10.1016/j.athoracsur.2010. 03.013 
13. Tabibiazar R, Cheung L, Han J, Swanson J, Beilhack A, An A, Dadras SS, Rockson N, Joshi S, Wagner R, Rockson SG (2006) Inflammatory manifestations of experimental lymphatic insufficiency. PLoS Med 3(7):e254. doi:10.1371/journal.pmed.0030254

14. Guo R, Zhou Q, Proulx ST, Wood R, Ji RC, Ritchlin CT, Pytowski B, Zhu Z, Wang YJ, Schwarz EM, Xing L (2009) Inhibition of lymphangiogenesis and lymphatic drainage via vascular endothelial growth factor receptor 3 blockade increases the severity of inflammation in a mouse model of chronic inflammatory arthritis. Arthritis Rheum 60(9):2666-2676. doi:10.1002/art.24764

15. Huggenberger R, Siddiqui SS, Brander D, Ullmann S, Zimmermann K, Antsiferova M, Werner S, Alitalo K, Detmar M (2011) An important role of lymphatic vessel activation in limiting acute inflammation. Blood 117(17):4667-4678. doi:10. 1182/blood-2010-10-316356

16. Chen L, Hamrah P, Cursiefen C, Zhang Q, Pytowski B, Streilein JW, Dana MR (2004) Vascular endothelial growth factor receptor-3 mediates induction of corneal alloimmunity. Nat Med 10(8):813-815. doi: $10.1038 / \mathrm{nm} 1078$

17. Dietrich T, Bock F, Yuen D, Hos D, Bachmann BO, Zahn G, Wiegand S, Chen L, Cursiefen C (2010) Cutting edge: lymphatic vessels, not blood vessels, primarily mediate immune rejections after transplantation. J Immunol 184(2):535-539. doi:10.4049/jimmunol.0903180

18. Nykanen AI, Sandelin H, Krebs R, Keranen MA, Tuuminen R, Karpanen T, Wu Y, Pytowski B, Koskinen PK, Yla-Herttuala S, Alitalo K, Lemstrom KB (2010) Targeting lymphatic vessel activation and CCL21 production by vascular endothelial growth factor receptor-3 inhibition has novel immunomodulatory and antiarteriosclerotic effects in cardiac allografts. Circulation 121(12):1413-1422. doi:10.1161/CIRCULATIONAHA. 109.910703

19. Yin N, Zhang N, Xu J, Shi Q, Ding Y, Bromberg JS (2011) Targeting lymphangiogenesis after islet transplantation prolongs islet allograft survival. Transplantation 92(1):25-30. doi:10. 1097/TP.0b013e31821d2661

20. Thomas SN, Rutkowski JM, Pasquier M, Kuan EL, Alitalo K, Randolph GJ, Swartz MA (2012) Impaired humoral immunity and tolerance in K14-VEGFR-3-Ig mice that lack dermal lymphatic drainage. J Immunol 189(5):2181-2190. doi:10.4049/ jimmunol.1103545

21. Cohen JN, Guidi CJ, Tewalt EF, Qiao H, Rouhani SJ, Ruddell A, Farr AG, Tung KS, Engelhard VH (2010) Lymph node-resident lymphatic endothelial cells mediate peripheral tolerance via Aire-independent direct antigen presentation. J Exp Med 207(4):681-688

22. Tewalt EF, Cohen JN, Rouhani SJ, Guidi CJ, Qiao H, Fahl SP, Conaway MR, Bender TP, Tung KS, Vella AT, Adler AJ, Chen L, Engelhard VH (2012) Lymphatic endothelial cells induce tolerance via PD-L1 and lack of costimulation leading to highlevel PD-1 expression on CD8 $\mathrm{T}$ cells. Blood 120(24):4772-4782. doi:10.1182/blood-2012-04-427013

23. Fletcher AL, Malhotra D, Turley SJ (2011) Lymph node stroma broaden the peripheral tolerance paradigm. Trends Immunol 32(1):12-18. doi:10.1016/j.it.2010.11.002

24. Tewalt EF, Cohen JN, Rouhani SJ, Engelhard VH (2012) Lymphatic endothelial cells-key players in regulation of tolerance and immunity. Front Immunol 3:305. doi:10.3389/fimmu.2012. 00305

25. Halin C, Detmar M (2008) Chapter 1. Inflammation, angiogenesis, and lymphangiogenesis. Methods Enzymol 445:1-25. doi:10.1016/S0076-6879(08)03001-2

26. Cursiefen C, Chen L, Borges LP, Jackson D, Cao J, Radziejewski C, D'Amore PA, Dana MR, Wiegand SJ, Streilein JW (2004) VEGF-A stimulates lymphangiogenesis and hemangiogenesis in inflammatory neovascularization via macrophage recruitment. J Clin Invest 113(7):1040-1050. doi:10.1172/JCI20465

27. Kataru RP, Jung K, Jang C, Yang H, Schwendener RA, Baik JE, Han SH, Alitalo K, Koh GY (2009) Critical role of CD11b+ macrophages and VEGF in inflammatory lymphangiogenesis, antigen clearance, and inflammation resolution. Blood 113(22):5650-5659. doi:10.1182/blood-2008-09-176776

28. Kim KE, Koh YJ, Jeon BH, Jang C, Han J, Kataru RP, Schwendener RA, Kim JM, Koh GY (2009) Role of CD11b+ macrophages in intraperitoneal lipopolysaccharide-induced aberrant lymphangiogenesis and lymphatic function in the diaphragm. Am J Pathol 175(4):1733-1745. doi:10.2353/ajpath. 2009.090133

29. Maruyama K, Ii M, Cursiefen C, Jackson DG, Keino H, Tomita M, Van Rooijen N, Takenaka H, D'Amore PA, Stein-Streilein J, Losordo DW, Streilein JW (2005) Inflammation-induced lymphangiogenesis in the cornea arises from CD11b-positive macrophages. J Clin Invest 115(9):2363-2372. doi:10.1172/JCI23874

30. Furtado GC, Marinkovic T, Martin AP, Garin A, Hoch B, Hubner W, Chen BK, Genden E, Skobe M, Lira SA (2007) Lymphotoxin beta receptor signaling is required for inflammatory lymphangiogenesis in the thyroid. Proc Natl Acad Sci USA 104(12):5026-5031. doi:10.1073/pnas.0606697104

31. Mounzer RH, Svendsen OS, Baluk P, Bergman CM, Padera TP, Wiig H, Jain RK, McDonald DM, Ruddle NH (2010) Lymphotoxin-alpha contributes to lymphangiogenesis. Blood 116(12):2173-2182. doi:10.1182/blood-2009-12-256065

32. Chauhan SK, Jin Y, Goyal S, Lee HS, Fuchsluger TA, Lee HK, Dana R (2011) A novel pro-lymphangiogenic function for Th17/ IL-17. Blood 118(17):4630-4634. doi:10.1182/blood-2011-01332049

33. Choi I, Lee YS, Chung HK, Choi D, Ecoiffier T, Lee HN, Kim KE, Lee S, Park EK, Maeng YS, Kim NY, Ladner RD, Petasis NA, Koh CJ, Chen L, Lenz HJ, Hong YK (2013) Interleukin-8 reduces post-surgical lymphedema formation by promoting lymphatic vessel regeneration. Angiogenesis 16(1):29-44. doi:10.1007/s10456-012-9297-6

34. Shao X, Liu C (2006) Influence of IFN-alpha and IFN-gamma on lymphangiogenesis. J Interferon Cytokine Res 26(8):568-574. doi:10.1089/jir.2006.26.568

35. Chaitanya GV, Franks SE, Cromer W, Wells SR, Bienkowska M, Jennings MH, Ruddell A, Ando T, Wang Y, Gu Y, Sapp M, Mathis JM, Jordan PA, Minagar A, Alexander JS (2010) Differential cytokine responses in human and mouse lymphatic endothelial cells to cytokines in vitro. Lymphat Res Biol 8(3):155-164. doi:10.1089/lrb.2010.0004

36. Kataru RP, Kim H, Jang C, Choi DK, Koh BI, Kim M, Gollamudi S, Kim YK, Lee SH, Koh GY (2011) T lymphocytes negatively regulate lymph node lymphatic vessel formation. Immunity 34(1):96-107. doi:10.1016/j.immuni.2010.12.016

37. Oka M, Iwata C, Suzuki HI, Kiyono K, Morishita Y, Watabe T, Komuro A, Kano MR, Miyazono K (2008) Inhibition of endogenous TGF-beta signaling enhances lymphangiogenesis. Blood 111(9):4571-4579. doi:10.1182/blood-2007-10-120337

38. Avraham T, Daluvoy S, Zampell J, Yan A, Haviv YS, Rockson SG, Mehrara BJ (2010) Blockade of transforming growth factorbeta1 accelerates lymphatic regeneration during wound repair. Am J Pathol 177(6):3202-3214. doi:10.2353/ajpath.2010. 100594

39. Johnson LA, Clasper S, Holt AP, Lalor PF, Baban D, Jackson DG (2006) An inflammation-induced mechanism for leukocyte transmigration across lymphatic vessel endothelium. J Exp Med 203(12):2763-2777. doi:10.1084/jem.20051759

40. Vigl B, Aebischer D, Nitschke M, Iolyeva M, Rothlin T, Antsiferova $\mathrm{O}$, Halin $\mathrm{C}$ (2011) Tissue inflammation modulates gene expression of lymphatic endothelial cells and dendritic cell 
migration in a stimulus-dependent manner. Blood 118(1):205-215. doi:10.1182/blood-2010-12-326447

41. Pegu A, Qin S, Fallert Junecko BA, Nisato RE, Pepper MS, Reinhart TA (2008) Human lymphatic endothelial cells express multiple functional TLRs. J Immunol 180(5):3399-3405

42. Martln-Fontecha A, Sebastiani S, Hopken UE, Uguccioni M, Lipp M, Lanzavecchia A, Sallusto F (2003) Regulation of dendritic cell migration to the draining lymph node: impact on $\mathrm{T}$ lymphocyte traffic and priming. J Exp Med 198(4):615-621

43. Brown MN, Fintushel SR, Lee MH, Jennrich S, Geherin SA, Hay JB, Butcher EC, Debes GF (2010) Chemoattractant receptors and lymphocyte egress from extralymphoid tissue: changing requirements during the course of inflammation. J Immunol 185(8):4873-4882. doi:10.4049/jimmunol.1000676

44. Sawa Y, Tsuruga E (2008) The expression of E-selectin and chemokines in the cultured human lymphatic endothelium with lipopolysaccharides. J Anat 212(5):654-663. doi:10.1111/j. 1469-7580.2008.00892.x

45. Maddaluno L, Verbrugge SE, Martinoli C, Matteoli G, Chiavelli A, Zeng Y, Williams ED, Rescigno M, Cavallaro U (2009) The adhesion molecule $\mathrm{L} 1$ regulates transendothelial migration and trafficking of dendritic cells. J Exp Med 206(3):623-635. doi:10. 1084/jem.20081211

46. Iolyeva M, Karaman S, Willrodt AH, Weingartner S, Vigl B, Halin C (2013) Novel role for ALCAM in lymphatic network formation and function. FASEB J 27:978-990. doi:10.1096/fj. $12-217844$

47. Vigl B, Zgraggen C, Rehman N, Banziger-Tobler NE, Detmar M, Halin C (2009) Coxsackie-and adenovirus receptor (CAR) is expressed in lymphatic vessels in human skin and affects lymphatic endothelial cell function in vitro. Exp Cell Res 315(2):336-347. doi:10.1016/j.yexcr.2008.10.020

48. Teijeira A, Garasa S, Pelaez R, Azpilikueta A, Ochoa C, Marre D, Rodrigues M, Alfaro C, Auba C, Valitutti S, Melero I, Rouzaut A (2013) Lymphatic endothelium forms integrinengaging 3D structures during DC transit across inflamed lymphatic vessels. J Investig Dermatol. doi:10.1038/jid.2013.152

49. Nitschke M, Aebischer D, Abadier M, Haener S, Lucic M, Vigl B, Luche H, Fehling HJ, Biehlmaier O, Lyck R, Halin C (2012) Differential requirement for ROCK in dendritic cell migration within lymphatic capillaries in steady-state and inflammation. Blood 120(11):2249-2258. doi:10.1182/blood-2012-03-417923

50. Lammermann T, Bader BL, Monkley SJ, Worbs T, WedlichSoldner R, Hirsch K, Keller M, Forster R, Critchley DR, Fassler R, Sixt M (2008) Rapid leukocyte migration by integrin-independent flowing and squeezing. Nature 453(7191):51-55. doi:10.1038/nature06887

51. Podgrabinska S, Kamalu O, Mayer L, Shimaoka M, Snoeck H, Randolph GJ, Skobe M (2009) Inflamed lymphatic endothelium suppresses dendritic cell maturation and function via Mac-1/ ICAM-1-dependent mechanism. J Immunol 183(3):1767-1779. doi:10.4049/jimmunol.0802167

52. Issa A, Le TX, Shoushtari AN, Shields JD, Swartz MA (2009) Vascular endothelial growth factor-C and CC chemokine receptor 7 in tumor cell-lymphatic cross-talk promote invasive phenotype. Cancer Res 69(1):349-357. doi:10.1158/0008-5472.CAN-08-1875

53. Miteva DO, Rutkowski JM, Dixon JB, Kilarski W, Shields JD, Swartz MA (2010) Transmural flow modulates cell and fluid transport functions of lymphatic endothelium. Circ Res 106(5):920-931. doi:10.1161/CIRCRESAHA.109.207274

54. Weber M, Hauschild R, Schwarz J, Moussion C, de Vries I, Legler DF, Luther SA, Bollenbach T, Sixt M (2013) Interstitial dendritic cell guidance by haptotactic chemokine gradients. Science 339(6117):328-332. doi:10.1126/science.1228456

55. Johnson LA, Jackson DG (2010) Inflammation-induced secretion of CCL21 in lymphatic endothelium is a key regulator of integrin-mediated dendritic cell transmigration. Int Immunol 22(10):839-849. doi:10.1093/intimm/dxq435

56. Beauvillain C, Cunin P, Doni A, Scotet M, Jaillon S, Loiry ML, Magistrelli G, Masternak K, Chevailler A, Delneste Y, Jeannin P (2011) CCR7 is involved in the migration of neutrophils to lymph nodes. Blood 117(4):1196-1204. doi:10.1182/blood2009-11-254490

57. Kabashima K, Shiraishi N, Sugita K, Mori T, Onoue A, Kobayashi M, Sakabe J, Yoshiki R, Tamamura H, Fujii N, Inaba K, Tokura Y (2007) CXCL12-CXCR4 engagement is required for migration of cutaneous dendritic cells. Am J Pathol 171(4):1249-1257. doi:10.2353/ajpath.2007.070225

58. Johnson LA, Jackson DG (2013) The chemokine CX3CL1 promotes trafficking of dendritic cells through inflamed lymphatics. J Cell Sci. doi:10.1242/jcs. 135343

59. Zhuo W, Jia L, Song N, Lu XA, Ding Y, Wang X, Song X, Fu Y, Luo Y (2012) The CXCL12-CXCR4 chemokine pathway: a novel axis regulates lymphangiogenesis. Clin Cancer Res 18(19):5387-5398. doi:10.1158/1078-0432.CCR-12-0708

60. Nielsen SR, Hammer T, Gibsona J, Pepperb MS, Nisatoc RE, Dissinga S, Tritsarisa K (2013) IL-27 inhibits lymphatic endothelial cell proliferation by STAT1-regulated gene expression. Microcirculation. doi:10.1111/micc.12055

61. Kang S, Lee SP, Kim KE, Kim HZ, Memet S, Koh GY (2009) Toll-like receptor 4 in lymphatic endothelial cells contributes to LPS-induced lymphangiogenesis by chemotactic recruitment of macrophages. Blood 113(11):2605-2613. doi:10.1182/blood2008-07-166934

62. Garrafa E, Imberti L, Tiberio G, Prandini A, Giulini SM, Caimi L (2011) Heterogeneous expression of toll-like receptors in lymphatic endothelial cells derived from different tissues. Immunol Cell Biol 89(3):475-481. doi:10.1038/icb.2010.111

63. Johnson LA, Prevo R, Clasper S, Jackson DG (2007) Inflammation-induced uptake and degradation of the lymphatic endothelial hyaluronan receptor LYVE-1. J Biol Chem 282(46):33671-33680. doi:10.1093/intimm/dxq435

64. Hou WH, Liu IH, Tsai CC, Johnson FE, Huang SS, Huang JS (2011) CRSBP-1/LYVE-1 ligands disrupt lymphatic intercellular adhesion by inducing tyrosine phosphorylation and internalization of VE-cadherin. J Cell Sci 124(Pt 8):1231-1244. doi: $10.1242 /$ jcs.078154

65. Platonova N, Miquel G, Regenfuss B, Taouji S, Cursiefen C, Chevet E, Bikfalvi A (2013) Evidence for the interaction of fibroblast growth factor-2 with the lymphatic endothelial cell marker LYVE-1. Blood 121(7):1229-1237. doi:10.1182/blood-2012-08-450502

66. Flister MJ, Wilber A, Hall KL, Iwata C, Miyazono K, Nisato RE, Pepper MS, Zawieja DC, Ran S (2010) Inflammation induces lymphangiogenesis through up-regulation of VEGFR-3 mediated by NF-kappaB and Prox1. Blood 115(2):418-429. doi:10.1182/blood-2008-12-196840

67. Kunstfeld R, Hirakawa S, Hong YK, Schacht V, Lange-Asschenfeldt B, Velasco P, Lin C, Fiebiger E, Wei X, Wu Y, Hicklin D, Bohlen P, Detmar M (2004) Induction of cutaneous delayed-type hypersensitivity reactions in VEGF-A transgenic mice results in chronic skin inflammation associated with persistent lymphatic hyperplasia. Blood 104(4):1048-1057. doi:10. 1182/blood-2003-08-2964

68. Halin C, Tobler NE, Vigl B, Brown LF, Detmar M (2007) VEGF-A produced by chronically inflamed tissue induces lymphangiogenesis in draining lymph nodes. Blood 110(9):3158-3167. doi:10.1182/blood-2007-01-066811

69. Angeli V, Ginhoux F, Llodra J, Quemeneur L, Frenette PS, Skobe M, Jessberger R, Merad M, Randolph GJ (2006) B celldriven lymphangiogenesis in inflamed lymph nodes enhances dendritic cell mobilization. Immunity 24(2):203-215. doi:10. 1016/j.immuni.2006.01.003 
70. Tan KW, Yeo KP, Wong FH, Lim HY, Khoo KL, Abastado JP, Angeli V (2012) Expansion of cortical and medullary sinuses restrains lymph node hypertrophy during prolonged inflammation. J Immunol 188(8):4065-4080. doi:10.4049/jimmunol.1101854

71. Nagy JA, Vasile E, Feng D, Sundberg C, Brown LF, Detmar MJ, Lawitts JA, Benjamin L, Tan X, Manseau EJ, Dvorak AM, Dvorak HF (2002) Vascular permeability factor/vascular endothelial growth factor induces lymphangiogenesis as well as angiogenesis. J Exp Med 196(11):1497-1506

72. Wirzenius M, Tammela $\mathrm{T}$, Uutela $\mathrm{M}$, He $\mathrm{Y}$, Odorisio $\mathrm{T}$, Zambruno G, Nagy JA, Dvorak HF, Yla-Herttuala S, Shibuya M, Alitalo K (2007) Distinct vascular endothelial growth factor signals for lymphatic vessel enlargement and sprouting. J Exp Med 204(6):1431-1440. doi:10.1084/jem.20062642

73. Enholm B, Karpanen T, Jeltsch M, Kubo H, Stenback F, Prevo R, Jackson DG, Yla-Herttuala S, Alitalo K (2001) Adenoviral expression of vascular endothelial growth factor-C induces lymphangiogenesis in the skin. Circ Res 88(6):623-629

74. Yao LC, Baluk P, Srinivasan RS, Oliver G, McDonald DM (2012) Plasticity of button-like junctions in the endothelium of airway lymphatics in development and inflammation. Am J Pathol 180(6):2561-2575. doi:10.1016/j.ajpath.2012.02.019

75. Zampell JC, Avraham T, Yoder N, Fort N, Yan A, Weitman ES, Mehrara BJ (2012) Lymphatic function is regulated by a coordinated expression of lymphangiogenic and anti-lymphangiogenic cytokines. Am J Physiol Cell Physiol 302(2):C392-C404. doi:10.1152/ajpcell.00306.2011

76. Zampell JC, Yan A, Elhadad S, Avraham T, Weitman E, Mehrara BJ (2012) CD4(+) cells regulate fibrosis and lymphangiogenesis in response to lymphatic fluid stasis. PLoS One 7(11):e49940. doi:10.1371/journal.pone.0049940

77. Tomura M, Honda T, Tanizaki H, Otsuka A, Egawa G, Tokura Y, Waldmann H, Hori S, Cyster JG, Watanabe T, Miyachi Y, Kanagawa O, Kabashima K (2010) Activated regulatory T cells are the major $\mathrm{T}$ cell type emigrating from the skin during a cutaneous immune response in mice. $\mathrm{J}$ Clin Invest 120(3):883-893. doi:10.1172/JCI40926

78. Bellingan GJ, Caldwell H, Howie SE, Dransfield I, Haslett C (1996) In vivo fate of the inflammatory macrophage during the resolution of inflammation: inflammatory macrophages do not die locally, but emigrate to the draining lymph nodes. J Immunol 157(6):2577-2585

79. Serhan CN, Chiang N, Van Dyke TE (2008) Resolving inflammation: dual anti-inflammatory and pro-resolution lipid mediators. Nat Rev Immunol 8(5):349-361. doi:10.1038/nri2294

80. Gautier EL, Ivanov S, Lesnik P, Randolph GJ (2013) Local apoptosis mediates clearance of macrophages from resolving inflammation in mice. Blood. doi:10.1182/blood-2013-01-478206

81. Cliff S, Bedlow AJ, Stanton AW, Mortimer PS (1999) An in vivo study of the microlymphatics in psoriasis using fluorescence microlymphography. Br J Dermatol 140(1):61-66

82. Ryan TJ (1980) Microcirculation in psoriasis: blood vessels, lymphatics and tissue fluid. Pharmacol Ther 10(1):27-64

83. Kovi J, Duong HD, Hoang CT (1981) Ultrastructure of intestinal lymphatics in Crohn's disease. Am J Clin Pathol 76(4):385-394

84. Van Kruiningen HJ, Colombel JF (2008) The forgotten role of lymphangitis in Crohn's disease. Gut 57(1):1-4. doi:10.1136/ gut.2007.123166

85. Liao S, Ruddle NH (2006) Synchrony of high endothelial venules and lymphatic vessels revealed by immunization. J Immunol 177(5):3369-3379

86. Lachance PA, Hazen A, Sevick-Muraca EM (2013) Lymphatic vascular response to acute inflammation. PLoS One 8(9):e76078. doi:10.1371/journal.pone.0076078

87. Kajiya K, Hirakawa S, Detmar M (2006) Vascular endothelial growth factor-A mediates ultraviolet B-induced impairment of lymphatic vessel function. Am J Pathol 169(4):1496-1503. doi:10.2353/ajpath.2006.060197

88. Shi VY, Bao L, Chan LS (2012) Inflammation-driven dermal lymphangiogenesis in atopic dermatitis is associated with $\mathrm{CD} 11 \mathrm{~b}+$ macrophage recruitment and VEGF-C up-regulation in the IL-4transgenic mouse model. Microcirculation 19(7):567-579. doi:10. 1111/j.1549-8719.2012.00189.x

89. Huggenberger R, Ullmann S, Proulx ST, Pytowski B, Alitalo K, Detmar M (2010) Stimulation of lymphangiogenesis via VEGFR-3 inhibits chronic skin inflammation. J Exp Med 207(10):2255-2269. doi:10.1084/jem.20100559

90. Kajiya K, Sawane M, Huggenberger R, Detmar M (2009) Activation of the VEGFR-3 pathway by VEGF-C attenuates UVBinduced edema formation and skin inflammation by promoting lymphangiogenesis. J Invest Dermatol 129(5):1292-1298. doi:10. 1038/jid.2008.351

91. Zhou Q, Guo R, Wood R, Boyce BF, Liang Q, Wang YJ, Schwarz EM, Xing L (2011) Vascular endothelial growth factor $\mathrm{C}$ attenuates joint damage in chronic inflammatory arthritis by accelerating local lymphatic drainage in mice. Arthritis Rheum 63(8):2318-2328. doi:10.1002/art.30421

92. Kajiya K, Huggenberger R, Drinnenberg I, Ma B, Detmar M (2008) Nitric oxide mediates lymphatic vessel activation via soluble guanylate cyclase alpha1beta1-impact on inflammation. FASEB J 22(2):530-537. doi:10.1096/fj.07-8873com

93. Breslin JW, Yuan SY, Wu MH (2007) VEGF-C alters barrier function of cultured lymphatic endothelial cells through a VEGFR-3-dependent mechanism. Lymphat Res Biol 5(2):105-113. doi:10.1089/lrb.2007.1004

94. Breslin JW (2011) ROCK and cAMP promote lymphatic endothelial cell barrier integrity and modulate histamine and thrombin-induced barrier dysfunction. Lymphat Res Biol 9(1):3-11. doi:10.1089/lrb.2010.0016

95. Rehal S, Blanckaert P, Roizes S, von der Weid PY (2009) Characterization of biosynthesis and modes of action of prostaglandin E2 and prostacyclin in guinea pig mesenteric lymphatic vessels. Br J Pharmacol 158(8):1961-1970. doi:10.1111/ j.1476-5381.2009.00493.x

96. Plaku KJ, von der Weid PY (2006) Mast cell degranulation alters lymphatic contractile activity through action of histamine. Microcirculation 13(3):219-227. doi:10.1080/10739680600556902

97. Liao S, Cheng G, Conner DA, Huang Y, Kucherlapati RS, Munn LL, Ruddle NH, Jain RK, Fukumura D, Padera TP (2011) Impaired lymphatic contraction associated with immunosuppression. Proc Natl Acad Sci USA 108(46):18784-18789. doi:10.1073/pnas. 1116152108

98. Breslin JW, Gaudreault N, Watson KD, Reynoso R, Yuan SY, Wu MH (2007) Vascular endothelial growth factor-C stimulates the lymphatic pump by a VEGF receptor-3-dependent mechanism. Am J Physiol Heart Circ Physiol 293(1):H709-H718. doi:10.1152/ajpheart.00102.2007

99. McKimmie CS, Singh MD, Hewit K, Lopez-Franco O, Le Brocq M, Rose-John S, Lee KM, Baker AH, Wheat R, Blackbourn DJ, Nibbs RJ, Graham GJ (2013) An analysis of the function and expression of D6 on lymphatic endothelial cells. Blood. doi:10. 1182/blood-2012-04-425314

100. Lee KM, McKimmie CS, Gilchrist DS, Pallas KJ, Nibbs RJ, Garside P, McDonald V, Jenkins C, Ransohoff R, Liu L, Milling S, Cerovic V, Graham GJ (2011) D6 facilitates cellular migration and fluid flow to lymph nodes by suppressing lymphatic congestion. Blood 118(23):6220-6229. doi:10.1182/blood-2011-03344044

101. Jamieson T, Cook DN, Nibbs RJ, Rot A, Nixon C, McLean P, Alcami A, Lira SA, Wiekowski M, Graham GJ (2005) The chemokine receptor D6 limits the inflammatory response in vivo. Nat Immunol 6(4):403-411. doi:10.1038/ni1182 
102. Neusser MA, Kraus AK, Regele H, Cohen CD, Fehr T, Kerjaschki D, Wuthrich RP, Penfold ME, Schall T, Segerer S (2010) The chemokine receptor CXCR7 is expressed on lymphatic endothelial cells during renal allograft rejection. Kidney Int 77(9):801-808. doi:10. 1038/ki.2010.6

103. Ohtani O, Ohtani Y (2008) Organization and developmental aspects of lymphatic vessels. Arch Histol Cytol 71(1):1-22

104. Norrmen C, Vandevelde W, Ny A, Saharinen P, Gentile M, Haraldsen G, Puolakkainen P, Lukanidin E, Dewerchin M, Alitalo K, Petrova TV (2010) Liprin (beta)1 is highly expressed in lymphatic vasculature and is important for lymphatic vessel integrity. Blood 115(4):906-909. doi:10.1182/blood-2009-03212274

105. Halin C, Fahrngruber H, Meingassner JG, Bold G, LittlewoodEvans A, Stuetz A, Detmar M (2008) Inhibition of chronic and acute skin inflammation by treatment with a vascular endothelial growth factor receptor tyrosine kinase inhibitor. Am J Pathol 173(1):265-277. doi:10.2353/ajpath.2008.071074

106. Muniz LR, Pacer ME, Lira SA, Furtado GC (2011) A critical role for dendritic cells in the formation of lymphatic vessels within tertiary lymphoid structures. J Immunol 187(2):828-834. doi:10.4049/jimmunol.1004233
107. Mu H, Calderone TL, Davies MA, Prieto VG, Wang H, Mills GB, Bar-Eli M, Gershenwald JE (2012) Lysophosphatidic acid induces lymphangiogenesis and IL-8 production in vitro in human lymphatic endothelial cells. Am J Pathol 180(5):2170-2181. doi:10.1016/j.ajpath.2012.03.003

108. Saito Y, Nakagami H, Morishita R, Takami Y, Kikuchi Y, Hayashi H, Nishikawa T, Tamai K, Azuma N, Sasajima T, Kaneda Y (2006) Transfection of human hepatocyte growth factor gene ameliorates secondary lymphedema via promotion of lymphangiogenesis. Circulation 114(11):1177-1184. doi:10. 1161/CIRCULATIONAHA.105.602953

109. Yoon CM, Hong BS, Moon HG, Lim S, Suh PG, Kim YK, Chae CB, Gho YS (2008) Sphingosine-1-phosphate promotes lymphangiogenesis by stimulating S1P1/Gi/PLC/Ca2+ signaling pathways. Blood 112(4):1129-1138. doi:10.1182/blood-2007$11-125203$

110. Yin N, Zhang N, Lal G, Xu J, Yan M, Ding Y, Bromberg JS (2011) Lymphangiogenesis is required for pancreatic islet inflammation and diabetes. PLoS One 6(11):e28023. doi:10. 1371/journal.pone.0028023 